\title{
Reproductive biology of the freshwater murrel Channa punctatus (Bloch, 1793) from River Gomti of Lucknow region, Uttar Pradesh, India
}

\author{
ANKUR KASHYAP, MADHU AWASTHI AND M. SERAJUDDIN* \\ Department of Zoology, University of Lucknow, Lucknow - 226 007, Uttar Pradesh, India \\ *Department of Zoology, University of Lucknow, Lukcnow - 226 007, Uttar Pradesh, India \\ e-mail:lu.fisheries@gmail.com
}

\begin{abstract}
A total of 187 samples of Channa punctatus (Bloch, 1793) from River Gomti of Lucknow region, Uttar Pradesh were studied during 2011. The sex ratio of 1: 0.84 was not significantly different from 1:1. Monthly variation in the gonadosomatic index (GSI) and maximum number of stage IV gonads encountered in the months of May to August indicated that the spawning season extends for about 4 months and spawning was high during the monsoon season. Absolute fecundity varied from 11000 to 28000 , with an average value of 14920 . Fecundity was found to be highly correlated to the total length $(\mathrm{r}=$ $0.9201)$, body weight $(\mathrm{r}=0.9133)$ and weight of ovary $(\mathrm{r}=0.8536)$ with all correlation coefficients being highly significant $(p<0.0001)$. Total length $(T L)$ of fish and weight of the ovary also highly correlated $(r=0.9551, p<0.0001)$. This study provides primary information on reproductive parameters of C. punctatus from River Gomti which can be utilised for management of the resource.
\end{abstract}

Keywords: Channa punctatus, Fecundity, Gonadosomatic index, Reproduction

Study of reproductive biology of fish is considered to be important from the evolutionary point of view and also in connection with rational management of the resource. Data pertaining to reproductive potential of fish is used in formulating the degree of rearing facilities needed and to assess the success of aquaculture ventures. Knowledge of the reproductive aspects like gonadosomatic index (GSI), maturity stages, fecundity and sex distribution, is required for better management in both culture and capture fisheries (De Carvalho et al., 2009; Fontoura et al., 2009).

The murrel, Channa punctatus (Bloch, 1793) is a freshwater fish commonly known as green snake-headed spotted murrel. C. punctatus is known to occur in lakes, ponds, rivers, impoundments, ditches and oxygen deficient swampy areas. Presence of accessory respiratory organs help the fish to survive in low oxygen conditions. The fish is also reported from brackishwater bodies (Pethiyagoda, 1991) and beels (Rahman, 1989). C. punctatus is distributed throughout the South Asian countries like Afghanistan, Pakistan, India, Sri Lanka, Nepal, Bangladesh, Myanmar and Yunnan in China (Froese and Pauly, 2015). The fish is economically important as a table fish and termed as 'lean fish' because of its very low lipid contents and absence of adipose tissues (Ghosh, 2006). Demand of the fish always exceeds the supply in local market in India and neighboring countries. It fetches a good price when sold alive particularly in northern, eastern and north-eastern parts of India.
Studies on breeding habits and spawning season of C. punctatus have been carried out earlier by a number of workers: Khan (1924) from Punjab; Mookerjee (1945), Qayyum and Qasim (1964) from Aligarh; Parameswaran and Murugesan (1976) from the swamps of Karnataka; Reddy (1979) from Guntur; Dehadrai (1976) from swamps and derelict waters of Barrackpore; Rath and Hajmadi (1976) from Bhuvaneswar; Marimuthu and Haniffa (2006) from Ilanthakulam; Prasad et al. (2011) from Allahabad; Kapil et al. (2011) from Amravati region and Saikia et al. (2013) from Assam. However, there is no recent detailed information about reproductive biology of $C$. punctatus especially from the River Gomti of Lucknow region. Therefore, the present study on annual reproductive cycle of $C$. punctatus collected from River Gomti of Lucknow region of Uttar Pradesh was undertaken with special reference to sex ratio, maturation of gonads, GSI and fecundity.

C. punctatus (Fig. 1) were randomly collected using cast and drag nets with the help of fisherman from River Gomti at Lucknow $\left(26^{\circ} 56^{\prime} \mathrm{N}\right.$; 80 $83^{\circ} 3^{\prime}$ E) during January 2011 to December 2011 at monthly intervals. A total of 187 samples ranging from 8.5 to $21.0 \mathrm{~cm}$ total length were collected. It was not possible to determine the sex by morphological characters, so an abdominal incision was made and the sex of the specimens was noted in fresh condition. Stage of maturity was determined following the scheme as suggested by Qayyum and Qasim (1964) for tropical and sub-tropical 


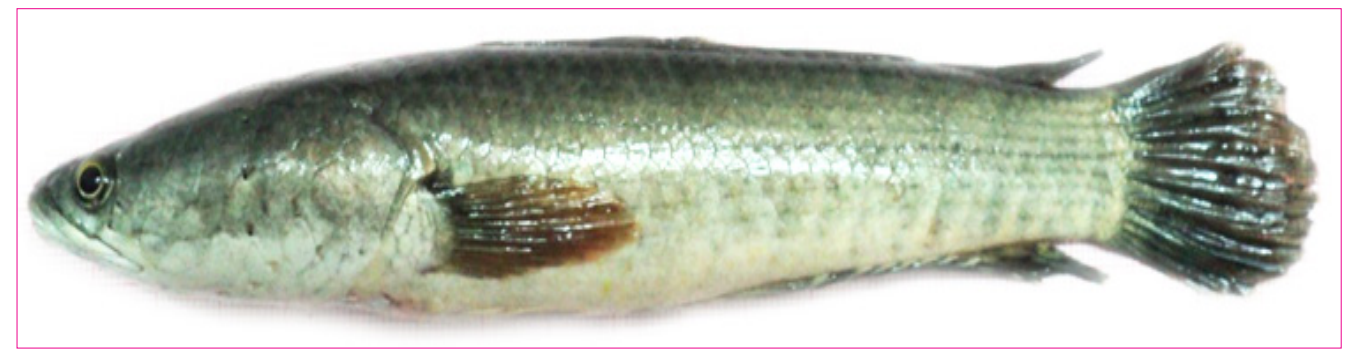

Fig. 1. C. punctatus collected from River Gomti from, Lucknow region

fishes. Identification of the stages of maturity were further determined after studying the gonad condition with respect to the colour, shape, transparency and extent of the gonads in the body cavity. Gonads were removed from the body and weighted on an electronic balance (precision $0.001 \mathrm{~g}$ ).

Gonadsomatic index (GSI) for each fish was computed by expressing the gonad weight as percentage of the total body weight. GSI was calculated using the standard formula:

$$
\mathrm{GSI}=\left(\mathrm{W}_{\mathrm{G}} / \mathrm{W}\right)^{*} 100
$$

where, $\mathrm{W}_{\mathrm{G}}=$ weight of gonad in $\mathrm{g}, \mathrm{W}=$ weight of the whole fish in $\mathrm{g}$. The reproductive season was determined using the GSI.

Fecundity studies were based on the examination of ripe gonads. The entire ovary was weighed and $100 \mathrm{mg}$ subsamples of eggs were removed from the anterior, middle and posterior regions of each ovary. The number of ova present in subsamples was counted and average number of subsamples was multiplied by the total weight of the ovary in order to calculate the absolute fecundity. The values for fecundity, body weight and body length were log transformed for normalisation. Correlation coefficient ' $r$ ' was determined to study the relationship between fecundity (F) and other parameters such as total length (TL), body weight (W) and weight of ovary (Wo). Covariance test was employed to find out the differences between fecundity and total length, fecundity and body weight as well as fecundity and ovary weight equations of relationship.

Of the 187 specimens of $C$. punctatus collected, 106 were males and 81 were females. The sex ratio varied with season. Monthly variations in number of males and females of C. punctatus are shown in Fig 2. The male and female ratio ranged from 1:0.50 to $1: 1.67$, with mean sex ratio being 1:0.84. However, Chi-square test showed no significant $(\mathrm{p}>0.05)$ departure from the hypothetical 1:1 ratio.

Testes were paired, elongated, creamy white in colour. The right testis was smaller as compared to left one and they were irregular in shape. Ovaries were also paired and elongated situated in the posterior part of the body cavity and suspended from the body wall by the mesovarium. Mature ovaries occupied nearly the whole of the body cavity. The two

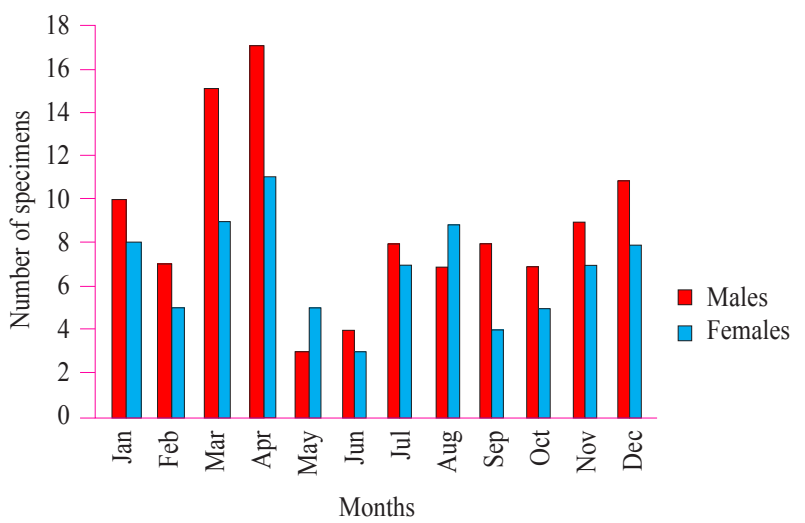

Fig. 2. Number of male and female specimens of C. punctatus sampled from River Gomti

lobes of the ovaries were free anteriorly but at the posterior end, they bend downwards and inwards to form a short single oviduct leading to the genital pore. Five mature stages were identified in both males and females (Table 1).

Changes in GSI in different months are presented in Fig. 3. Low GSI index indicated the inactive phase of the gonads. As gonadal activity picked up, GSI also increased attaining its peak value in the ripe stage. In both the case, lowest values of GSI were recorded in both sexes from October to February. The value gradually increased from March, when the ovaries began to mature to reach the maximum in August, when most of the adults were fully

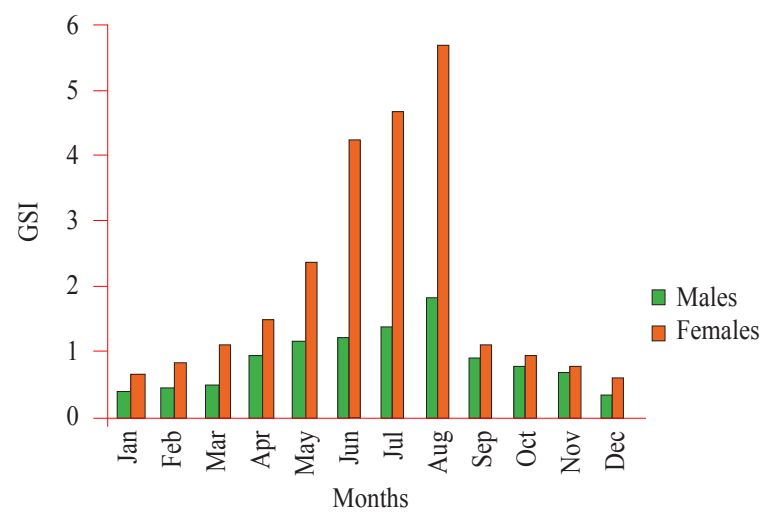

Fig. 3. Monthly GSI of $C$. punctatus in one annual cycle 
Table 1. Five maturity stages of gonads in C. punctatus

\begin{tabular}{|c|c|c|}
\hline Stage & Testes & Ovaries \\
\hline I (Immature virgin) & $\begin{array}{l}\text { Testes small, transparent and pinkish in colour and } \\
\text { vas deferens not distinct. }\end{array}$ & $\begin{array}{l}\text { Ovary thin, elongated, cylindrical, occupy less than } \\
\text { half length of the body cavity. Light pink in colour, } \\
\text { transparent and irregular in shape. Eggs not visible to } \\
\text { naked eye but distinct under microscope. }\end{array}$ \\
\hline $\begin{array}{l}\text { II (Maturing virgin } \\
\text { and recovering spent) }\end{array}$ & $\begin{array}{l}\text { Each testis elongated, distended, whitish and opaque. } \\
\text { vas deferens wide but reduced. }\end{array}$ & $\begin{array}{l}\text { Ovary thin, extended slightly more than half the length } \\
\text { of the body cavity, pink in colour, ova not visible } \\
\text { to naked eye, but nucleus visible, initiation of yolk } \\
\text { deposition evident. }\end{array}$ \\
\hline III (Ripening) & $\begin{array}{l}\text { Testes extensive than before, dull pink in colour and } \\
\text { opaque. Viscous fluid oozes out on slight pressure. }\end{array}$ & $\begin{array}{l}\text { Ovary light yellow in colour, lobulated, occupy almost } \\
\text { entire body cavity. Ova opaque and clearly visible to } \\
\text { naked eye. }\end{array}$ \\
\hline IV (Ripe) & $\begin{array}{l}\text { Testes elongated and pink in colour, very much distended. } \\
\text { Milt oozes out on slight pressure on abdomen. } \\
\text { vas deferens not discernible. }\end{array}$ & $\begin{array}{l}\text { Ovary light yellow distended, occupying entire body } \\
\text { cavity. Ova clearly visible to naked eye. }\end{array}$ \\
\hline V (Spent) & $\begin{array}{l}\text { Testes white or creamy white in colour, weight drastically } \\
\text { reduced. No milt on pressure. }\end{array}$ & $\begin{array}{l}\text { Ovaries flaccid, contracted, blood-slot and baggy. } \\
\text { Remnants of mature ova noticed in recently spawned } \\
\text { ovary. }\end{array}$ \\
\hline
\end{tabular}

mature. In September, gradual drop in GSI was noted which may be due to presence of spent adults.

Spawning season of $C$. punctatus in the present study was estimated on the basis of occurrence of adults in different stages of maturity in each month. Since the ripe gonads (stage IV) which mainly encountered from May to August with greater number during July to August coincided with high value of GSI indicating the spawning period of C. punctatus with peak during July and August.

In the present study, absolute fecundity of C. punctatus varied between 11000 to 28000 with an average of 14920 . Absolute fecundity was found to be highly correlated with the total length (TL), body weight (W) and weight of ovary $\left(\mathrm{W}_{\mathrm{O}}\right)$ with values of correlation coefficients ( $\mathrm{r}$ ) as 0.9201, 0.9133 and 0.8536 respectively (Table 2 ). All the values of correlation coefficients $(\mathrm{r})$ obtained in the present study were highly significant $(\mathrm{p}<0.0001)$. Similarly, highly significant $(p<0.0001)$ correlation was noted between the total length (TL) and weight of the ovary with value of correlation coefficient (r) as 0.9551 (Table 2). The value of ' $b$ ' for fecundity-body length relationship was found to be 1.927 in the present study.

Males outnumbered females in the population of C. punctatus which could be due to higher mortality of females in the natural environment. Mortality of female individuals of $C$. punctatus can be related to the natural causes as spawning stress. Several workers reported high number of males in fish populations (Gowda and Shanbhogue, 1988; Hoda and Qureshi, 1989; Abujam and Biswas, 2011). However, the sex ratio noted here did not depart significantly from the hypothetical sex ratio of $1: 1$. The cycle of maturation and depletion of gonads is synchronised in both sexes. In the present study, most of the stage IV ripe gonads were recorded from May to August and spawning was found to be at its peak in core monsoon months during July-August. The breeding behaviour of $C$. punctatus seems to follow the same pattern which is common to all freshwater fishes in the plains of western Uttar Pradesh. As regards to Indian freshwater fishes, a perusal of literature with respect to the spawning seasons revealed that most species have relatively short spawning seasons and most of them spawn after the onset of south-west monsoon which begins in the extreme south-western part of India in late May and gradually progresses northwards. In most part of India, the monsoon begins in the middle of June and the rivers, lakes and ponds are flooded during July to October, which coincides with the spawning season of most species. Qasim and Qayyum (1961) found July - September to be the breeding season of many freshwater teleosts found in the plains of Uttar Pradesh and further emphasised that breeding has direct relation with

Table 2. Logarithmic regression equations of various relationships in C. punctatus

\begin{tabular}{lll}
\hline Relationship & Logarithmic regression equation & Correlation coefficient ' $r$ ' \\
\hline Fecundity-Total length & $\log F=1.864+1.927 \log \mathrm{TL}$ & 0.9201 \\
Fecundity-Body weight & $\log \mathrm{F}=3.166+0.6143 \log \mathrm{W}$ & 0.9133 \\
Fecundity-Weight of ovary & $\log \mathrm{F}=3.957+0.5173 \log \mathrm{W}_{\mathrm{O}}$ & 0.8536 \\
Total length-Weight of ovary & $\log \mathrm{W}_{\mathrm{O}}=-3.541+3.302 \log \mathrm{TL}$ & 0.9551 \\
\hline
\end{tabular}


monsoon cycle. Present finding is also in accordance with the findings of Reddy (1979) in C. punctatus collected form Guntur, Andhra Pradesh.

Five maturity stages were recorded during the present study following the scheme of classification given by Qayyum and Qasim (1964). But, Reddy (1979) recognised seven stages of maturity in $C$. punctatus. The observations regarding the maturity stages and spawning was further supported by the GSI values.

Highly significant $(\mathrm{p}<0.0001)$ linear correlations between the fecundity and total length (TL), body weight (W) and weight of ovary $\left(\mathrm{W}_{\mathrm{O}}\right)$ in C. punctatus in the present study indicated that fecundity increased with respect to the increase in total length (TL), body weight (W) and weight of ovary $\left(\mathrm{W}_{\mathrm{O}}\right)$. Similar results in C. punctatus were also reported by Marimuthu and Haniffa (2006), Prasad et al. (2011) and Amzad et al. (2015). Kesteven (1942) reported that the number of ova holds exponential relation with the length of the fish in the same way as does the weight. A wide range of the value of ' $b$ ' for fecundity-body length relationship was reported by several workers. Prasad et al. (2011) and Saikia et al. (2013) reported the value of ' $b$ ' for fecundity-body length relationship as 3.02 and 2.08 in C. punctatus. Devraj (1973) reported the value of ' $b$ ' for fecundity-body length relationship as 1.6 in Ophiocephalus marulius. The value of ' $b$ ' for fecundity-body weight relationship in the present study was much lower than that for the fecundity-body length relationship, suggesting that the rate of egg production in relation to increase in weight of this fish was lower than the rate of egg production in relation to increase in length (Table 2). Results of the present study provided detailed information regarding the reproductive biology of C. punctatus of River Gomti with special reference to its spawning and breeding season, sex distribution and maturation of gonads which could be useful for management of the resource in the wild water bodies as well as for captive seed production of the species for aquaculture.

\section{References}

Amzad, H. M., Sohel, M., Mariya, A., Fazley, R. A. and Sabiha, M. 2015. Ovarian biology of spotted snakehead (Channa punctatus) from natural wetlands of Sylhet, Bangladesh. Ann. Vet. Anim. Sci., 2: 64-76.

Abujam, S. S. and Biswas, S. P. 2011. Studies on the reproductive biology of spiny eel, Macrognathus aral from upper Assam. $J$. Environ. Biol., 32: 635-639.

De Carvalho, P. A., Paschoalini, A. L., Santos, G. B., Rizzo, E. and Bazzoli, N. 2009. Reproductive biology of Astyanax fasciatus (Pisces: Characiformes) in a reservoir in south eastern Brazil. J. Appl. Ichthyol., 25: 306-313.
Dehadrai, P. V. 1976. Culture of air breathing fishes in derlict water. All India co-ordinated research project on air breathing fish culture, Central Inland Fishries Research Institute, Barrackpore, India. p. 1-8.

Devaraj, M. 1979. Biology of the large snake headed Ophiocephalus marulius (Ham.) in Bhawani Sagar waters. Indian. J. Fish., 20: 280-307.

Fontoura, N. F., Braun, A. S. and Milani, P. C. C. 2009. Estimating size at first maturity (L50) from gonadosomatic index (GSI) data. Neotrop. Ichthyol., 7: 217-222.

Froese, R. and Pauly, D. 2015. Fish Base. World Wide Web electronic publication. http://www.fishbase.org (Accessed 9 April 2015)

Ghosh, S. 2006. Composition and distribution of lipids and fatty acids in two jeol fishes of West Bengal. Ph.D. thesis, University of Calcutta, Calcutta, India.

Gowda, G. and Shanbhogue, S. L. 1988. On the reproductive biology of grey mullet Valamugil seheli (Forskal) from Mangalore waters. Mahasagar, 21: 105-112.

Hoda, S. S. M. and Qureshi, N. 1989. Maturity, sex ratio, ova diameter and fecundity of the mullet, Liza klunzingeri Day from Karachi-Sind waters. Indian. J. Fish., 36: 183-192.

Kapil, S., Kulkarni, K. M., Gijare, S. S. and Tantarpale, T. 2011. Seasonal changes of gonadosomatic index observed in the freshwater fish Channa punctatus. The Bioscan, 6: 571-573.

Kesteven, G. L. 1942. Studies on the biology of Australian mullet. HE Daw, http://catalogue.nla.gov.au/record/20542

Khan, H. 1924. Observations on the breeding habits of some freshwater fishes in the Punjab. Bombay Natur. Hist. Soc. J., 29: $958-962$

Marimuthu, K. and Haniffa, M. A. 2006. Studies on fecundities of captive reared spotted snake head Channa punctatus (Channidae). J. Fish. Aquat. Sci., 1: 291-296.

Mookerjee, H. K. 1945. Identification of eggs of common freshwater fishes of Bengal. Sci. Cult., 9: 40.

Parameswaran, S. and Murugesan, V. K. 1976. Observations on the hypophysation of murrels (Ophicephalidae). Hydrobiologia, 50: 81-87.

Pethiyagoda, R. 1991. Freshwater fishes of Sri Lanka. Wildlife Heritage Trust of Sri Lanka, Colombo.

Prasad, L., Dwivedi, A. K., Dubey, V. K. and Serajuddin, M. 2011. Reproductive biology of freshwater murrel, Channa punctatus (Bloch, 1793) from river Varuna (A tributary of Ganga River) in India. J. Ecophysiol. Occup. Health, 11: 69-80.

Qasim, S. Z. and Qayyum, A. 1961. Spawning frequencies and breeding seasons of some freshwater fishes with special reference to those occurring in the plains of Northern India. Indian. J. Fish., 8: 24-43. 
Qayyum, A. and Qasim, S. Z. 1964. Studies on the biology of some freshwater fishes. Part. I Ophiocephalus punctatus Bloch. Bombay Natur. Hist. Soc. J., 61: 74-98.

Rahman, A. 1989. Freshwater fisheries of Bangladesh. Zoological Society of Bangladesh, Bangladesh.

Rath, R. and Hajmadi, P. M. 1976. The fecundity of Ophiocephalus punctatus (Pisces, Channidae). J. Zool. Soc. Ind., 28: 1-6.
Reddy, B. P. 1979. Maturity and spawning in the murrel, Channa punctatus (Bloch, 1793) (Pisces, Teleostei, Channidae) from Guntur, Andhra Pradesh. Proc. Indian Nat. Sci. Acad. Part B, 45: 543-553.

Saikia, A. K., Abujam, S. S. and Biswas S. P. 2013. Reproductive biology of Channa punctatus (Bloch) from paddy field of Sivasagar, Assam. Int. J. Curr. Res., 5: 542-546.

Date of receipt $\quad: 05.05 .2015$

Date of acceptance : 17.08 .2016 